\title{
PERMINTAAN DAN PENDAPATAN PEDAGANG BUAH JERUK BRASTAGI DI TINGKAT PENGECER DI KOTA BENGKULU
}

\author{
Satria Putra Utama ${ }^{1}$ \\ Sri Sugiarti ${ }^{1}$ \\ Bosko Purba 2 \\ ${ }^{1}$ Staf Pengajar Jurusan Sosial Ekonomi Pertanian Fak.Pertanian UNIB \\ 2 Alumni Jurusan Sosial Ekonomi Pertanian Fak.Pertanian UNIB
}

\begin{abstract}
Retailer demand on Brastagi orange is derivate from consumers demand or people in Bengkulu city. On the other hand, there were some factors that influenced demand of Brastagi orange on retailers themselves beside influencing by factor from consumer, like: the number of Brastagi orange that ordered or bought by retailer in the last month, the price of Brastagi orange bought in this month, the price of Brastagi orange in the retailer in this month, the price of Brastagi orange on the retailer in the last month, the price of Bengkulu (local) orange in the retailer, the number of Brastagi orange that ordered or bought by consumers in the last month, capital and dummy of place for retailers. Descriptive analysis was shows that the biggest number of month ordered of Brastagi orange is the demand of Brastagi Orange on AB type in awning retailer, on the other side the biggest demand for Brastagi orange from the retailer without awning is on super type with the source of the whole buying from the agent in Bengkulu City. The system of payment from the agent is pay after sale. The result of data analysis and hypothesis test (t test) shows that the price of retailer Brastagi Orange order in this month (X1), capital (X3), the number of Brastagi orange that bought in the last month (x4t-1), and dummy of trade location (D) were influenced or significant as partial on Brastagi orange retailer demand . On the other side, the price of Bengkulu Local orange (X2) was not influence on retailer demand on retailer Brastagi orange. The result of the income analysis were shows that the amount of income from Brastagi orange retailer with awning per month and the income of the Brastagi orange retailer without awning month. However, the result of analysis from statistic test shows that different of income retailer with awning compare to retailer without awning was not significant.
\end{abstract}

Key words : demand, income, brastagi orange

\section{PENDAHULUAN}

Hortikultura sebagai sub sektor pertanian yang meliputi sayuran, tanaman hias, dan buah - buahan banyak diusahakan oleh petani terutama di pedesaan. Sektor ini perlu mendapat dukungan dan perhatian yang serius, terutama dalam hal pasca panen yang semakin baik. Upaya pemerintah Indonesia untuk diversifikasi pangan, komoditi buah-buahan semakin berpeluang untuk dikembangkan. Diharapkan permintaan akan meningkat akibat adanya; (a) peningkatan jumlah penduduk, (b) peningkatan pendapatan masyarakat, (c) peningkatan pengetahuan dan (d) kesadaran masyarakat terhadap gizi. Jeruk Brastagi yang dikenal umum dengan nama jeruk Siam merupakan anggota jeruk Keprok yang banyak diusahakan dan paling luas penyebarannya di Indonesia. Disebut Jeruk Brastagi karena jeruk Siam yang terdapat di Sumatera ada di daerah Brastagi. Di Sumatera Utara, tanaman jeruk sudah lama dikenal dan dibudidayakan oleh petani, 
dimana daerah Kabupaten Karo ( Brastagi ) merupakan daerah penghasil buah jeruk yang terbanyak di Sumatera Utara.

Permintaan konsumen rumah tangga akan komoditi pertanian dalam hal ini Jeruk Brastagi adalah banyaknya komoditi jeruk yang dibutuhkan dan dibeli oleh konsumen, merupakan contoh dari permintaan konsumen. Besar kecilnya komoditi jeruk Brastagi umumnya dipengaruhi oleh harga, harga substitusi atau harga komplemennya, selera dan keinginan, jumlah konsumen dan pendapatan konsumen yang bersangkutan. Sedangkan permintaan pedagang pengecer dalam hal ini buah jeruk Brastagi merupakan permintaan turunan ( Hanafiah dan Saefudin, 1983 ). Maka semua jenis permintaan itu berasal dari permintaan konsumen pada tingkat eceran Bengkulu sebagai salah satu propinsi di Indonesia mempunyai daya tarik tersendiri bagi para pencari kerja khususnya dari luar propinsi, dalam mencari pekerjaan yang sesuai dengan kemampuan dan keahlian dalam bidang masing-masing. Keberadaan sektor informal di Kota Bengkulu ini perlu mendapat perhatian khusus dari pemerintahan daerah, karena sektor ini mampu menyerap tenaga kerja yang cukup besar dan bersifat mandiri. Salah satu bidang usaha di sini adalah pedagang buah-buahan khususnya pedagang buah Jeruk Brastagi di lokasi Pasar Minggu dan Pasar Panorama Kota Bengkulu, yang menyalurkan kebutuhan pokok sehari-hari khususnya buah-buahan hingga ke konsumen akhir.

Bengkulu khususnya di Pasar Minggu dan Pasar Panorama Kota Bengkulu dari waktu ke waktu jumlah pedagang buah semakin bertambah khususnya pedagang buah Jeruk Brastagi yang hampir menguasai pasar buah. Penambahan jumlah buah jeruk Brastagi ini ke Kota Bengkulu memberikan gambaran bahwa jeruk tersebut benar-benar diminta oleh konsumen masyarakat Bengkulu khususnya masyarakat yang berpenghasilan menengah ke atas. Pemasokan buah jeruk ini yang selalu kontinue khususnya yang selalu diminta para pedagang pengecer membuktikan bahwa Jeruk Brastagi ini laku di pasar-pasar khususnya di Pasar Minggu dan Pasar Panorama Kota Bengkulu baik pedagang pengecer pada Auning juga pedagang pengecer yang Emperan. Hal ini terlihat bahwa jeruk Brastagi tersebut dari hari ke hari nampak segar artinya arus penjualan jeruk ini selalu lancar sehingga tidak sampai bertahan lama di gudang-gudang.

\section{METODE PENELITIAN}

\section{Penentuan Lokasi Penelitian dan Responden}


Penentuan lokasi penelitian dilakukan secara sengaja (purposive) yaitu di Pasar Minggu dan Pasar Panorama Kota Bengkulu, dengan alasan 1) Letak Pasar Minggu dan Pasar Panorama berada di Kota Bengkulu, sehingga mudah dijangkau dan Banyaknya penjual buahbuahan khususnya pedagang buah jeruk Brastagi dan 2) juga para konsumen yang keluar masuk pasar yang dapat ditemui karena merupakan daerah keramaian dan lintasan transportasi. Penentuan responden dilakukan dengan metode sensus. Responden keseluruhan adalah 40 orang, yaitu di Pasar Minggu 10 orang pedagang pengecer auning dan 10 orang pedagang pengecer emperan, sedangkan untuk Pasar Panorama sebanyak 10 orang pedagang pengecer auning dan 10 orang pedagang pengecer emperan.

\section{Analisis Faktor-faktor yang mempengaruhi permintaan buah jeruk Brastagi}

Alat analisis yang digunakan untuk menganalisis faktor-faktor yang mempengaruhi permintaan adalah dengan menggunakan fungsi linier berganda, dengan mengacu pada beberapa asumsi yaitu:

- Fluktuasi perubahan kuantitas buah jeruk Brastagi dianggap sama

- Fluktuasi perubahan harga beli buah jeruk Brastagi dianggap sama

- Fluktuasi perubahan kuantitas buah-buahan yang lain dianggap sama

- Fluktuasi perubahan harga beli buah-buahan yang lain dianggap sama.

Secara matematis fungsi linier berganda tersebut dapat ditulis sebagai berikut:

$$
Y=b_{0}+b_{1}(y t-1)+b_{2} X_{1}+b_{3}\left(X_{1} t-1\right)+b_{4} X_{2}+b_{5} X_{3}+b_{6}\left(X_{4} t-1\right)+b_{7} D+e i
$$

Keterangan :

$\mathrm{Y}=$ Total Permintaan jeruk Brastagi pada pedagang pengecer ( $\mathrm{Kg} / \mathrm{bulan})$

bo $=$ intersep / konstanta

$\mathrm{bi}=$ koefisien regresi

yt-1 = Jumlah jeruk Brastagi yang diminta atau dibeli pada pedagang pengecer bulan lalu (kg)

$\mathrm{X} 1$ = Harga beli jeruk Brastagi pada pedagang pengecer bulan ini (Rp/kg)

$\mathrm{X}_{\mathrm{t}} \mathrm{t}-1=$ Harga beli jeruk Brastagi pada pedagang pengecer pada bulan lalu ( $\mathrm{Rp} / \mathrm{kg}$ )

$X_{2}=$ Harga beli Jeruk Lokal Bengkulu pada pedagang pengecer ( Rp/kg)

$X_{3}=$ Modal Usaha $(R p)$

$\mathrm{X}_{4} \mathrm{t}-1$ = jumlah jeruk Brastagi yang dibeli oleh konsumen bulan lalu $(\mathrm{Kg})$

$\mathrm{D} \quad=$ pedagang pengecer $(1=$ pengecer auning dan $0=$ pengecer emperan

ei $=$ kesalahan pengganggu

Pendapatan usaha penjualan buah jeruk Brastagi dihitung dengan rumus penerimaan usaha dikurangi biaya total usaha. Disamping menggunakan selisih penerimaan dengan total biaya mengenai pendapatan, dilakukan pula uji statistik untuk membuktikan dugaan bahwa 
pendapat anyang di peroleh pedagang pegecer auning lebih besar dari pedagang pengecer emperan, dilakukan dengan uji beda nilai tengah (uji t) .

\section{HASIL DAN PEMBAHASAN}

\section{Permintaan Buah Jeruk Brastagi Pada Pedagang Pengecer Kota Bengkulu.}

Permintaan jeruk Brastagi pada pedagang pengecer auning sebesar $1.398 \mathrm{Kg}$ lebih besar dari tingkat permintaan pedagang pengecer emperan yang hanya sebesar $1.122 \mathrm{Kg}$. Diperoleh juga bahwa jeruk Brastagi yang paling banyak diminta atau dibeli oleh pedagang pengecer di Kota Bengkulu adalah jeruk Brastagi kelas AB sebanyak 34,90 \% Untuk pedagang yang memiliki jenis tempat auning dan untuk pedagang pengecer yang memiliki jenis tempat emperan adalah kelas Super sebesar $35,56 \%$. Namun dari hasil penelitian menunjukkan bahwa permintaan pedagang pengecer Auning terhadap jeruk Brastagi baik kelas Super, AB dan kelas $C$ tidak memiliki perbedaan yang cukup jauh. Demikian juga untuk pedagang pengecer emperan bahwa permintaan terhadap jeruk Brastagi untuk masing-masing jenis tidak memiliki perbedaan yang terlalu jauh atau dapat dikatakan antara tiga kelas jeruk Brastagi yang diminta pedagang pengecer memiliki porsi yang seimbang .

Untuk harga beli rata-rata jenis super pada pedagang pengecer Auning adalah sebesar Rp 7041 per kilogram dan harga jualnya rata-rata Rp 8732,82 per kilogramnya, angka ini lebih tinggi dari harga beli rata-rata jenis super untuk pengecer emperan yang hanya Rp 6852 per kilogramnya dan harga jual rata-ratanya Rp 8713 per kilogram. Untuk jenis $A B$, bahwa harga beli rata-rata pengecer auning Rp 5502 per kilogram dan harga jual rata-rata Rp 7107,47 per kilogram. Sedangkan untuk pengecer emperan bahwa harga beli rata-rata jeruk jenis AB Rp 5374 per kilogram dan harga jual rata-ratanya Rp 7103 per kilogram. Angka ini juga mengindikasikan bahwa untuk pedagang auning harga beli rata-rata Rp 4288 per $\mathrm{Kg}$ dan harga jual rata-rata Rp 5520,58 per Kg, sementara untuk pengecer emperan harga beli rata-rata RP 4353 per Kg dan harga jual rata-rata $\mathrm{Rp} 5761$ per $\mathrm{Kg}$.

Dengan melihat tingkat permintaan pada pedagang pengecer Auning lebih besar dari permintaan pedagang pengecer emperan. Maka hal ini cukup beralasan karena pedagang pengecer auning pada umumnya terletak di tengah pasar dimana calon konsumen jauh lebih banyak dibandingkan dengan pengecer emperan yang terletak di pinggir pasar atau di pinggir jalan sekitar pasar, yang hanya mengandalkan calon konsumen yang lalu lalang. Juga disebabkan bahwa konsumen lebih memilih jeruk Brastagi pada pedagang pengecer auning 
daripada jeruk Brastagi yang dijual pada pedagang pengecer emperan, hal itu ditunjukkan dari segi kebersihan atau penjajaan yang lebih bagus pada pedagang pengecer auning dibandingkan pada pedagang pengecer emperan yang mengakibatkan pada tingkat permintaan yang dilakukan oleh pedagang pengecer itu sendiri.

Pada umumnya pedagang pengecer jeruk Brastagi membeli jeruk dari agen dan selanjutnya dijual kepada konsumen. Jeruk ini dipasok dari Brastagi Kabupaten Karo Sumatera Utara. Pada umumnya antara agen dengan pedagang pengecer sudah saling mengenal karena ada ikatan family, atau juga karena ikatan Marga sehingga pedagang pengecer jeruk Brastagi dan agen perantara sudah saling percaya dan tidak heran lagi kalau harga beli masing-masing pedagang pengecer kadang-kadang tidak sama karena dipengaruhi faktor kekeluargaan antara agen dan pedagang. Maka dari hasil penelitian membuktikan bahwa cara pembayaran pedagang pengecer terhadap agen dilakukan dengan cara pembayaran "dibelakang " artinya agen menerima bayaran dari pedagang setelah jeruk Brastagi laku terjual dan biasanya dilakukan pembayaran seminggu setelah pembelian dari agen. Berbeda halnya dengan sistem pembayaran antara pedagang pengecer dengan konsumen semuanya dilakukan dengan sistem pembayaran langsung atau tunai pada saat pembelian buah jeruk Brastagi tersebut.

Pada umumnya pedagang pengecer di Kota Bengkulu menjual buah-buahan bukan hanya jeruk Brastagi saja tetapi juga menjual beberapa buah-buahan lain seperti jeruk manis lokal, apel merah, apel fuji, salak, buah pear, dan buah anggur seperti terlihat pada Tabel 1.

Tabel 1. Rata- rata Permintaan Bulanan Buah-buahan lain pada Pedagang Pengecer di Kota Bengkulu

\begin{tabular}{lrrrrrr}
\hline Jenis Buah & \multicolumn{3}{c}{ Auning } & \multicolumn{3}{c}{ Emperan } \\
\cline { 2 - 7 } & \multicolumn{2}{c}{$\begin{array}{l}\text { Permintaan \% } \\
(\mathrm{Kg})\end{array}$} & $\begin{array}{c}\text { H. Beli } \\
(\mathrm{Rp} / \mathrm{kg})\end{array}$ & $\begin{array}{c}\text { Jumlah } \\
(\mathrm{Kg})\end{array}$ & $\begin{array}{c}\text { H. Beli } \\
(\mathrm{Rp} / \mathrm{kg})\end{array}$ \\
\hline 1. Jeruk manis & 221 & 32,55 & 2358 & 214 & 31,05 & 2354 \\
2. Apel merah & 112 & 16,49 & 11192 & 123 & 17,85 & 11370 \\
3. Apel fuji & 105 & 15,46 & 10890 & 107 & 15,52 & 10842 \\
4. Salak & 107 & 15,75 & 2514 & 113 & 16,40 & 2434 \\
5. Buah pear & 96 & 14,13 & 10667 & 86 & 12,48 & 10795 \\
6. Buah anggur & 38 & 5,62 & 22885 & 46 & 6,7 & 22817 \\
\hline
\end{tabular}

Sumber : Data primer diolah 
Pada Tabel 1 dapat dilihat bahwa buah - buahan lain yang paling banyak diminta oleh pedagang pengecer auning adalah buah jeruk manis lokal Bengkulu yakni sebanyak 32,55\% dengan harga beli rata-rata $\mathrm{Rp} 2358$ per kg, demikian juga untuk pedagang pengecer emperan bahwa permintaan buah-buahan lain yang paling tinggi adalah jeruk manis lokal Bengkulu dengan harga beli rata-rata Rp 2354 per $\mathrm{kg}$. Dari kedua jenis tempat usaha ini ternyata tidak memiliki perbedaan yang cukup jauh baik dari segi tingkat permintaannya maupun dari harga belinya. Tingginya tingkat permintaan buah jeruk manis lokal ini oleh pedagang pengecer karena disamping harga beli murah juga jeruk manis lokal ini laku di pasar karena sekaligus sebagai buah substitusi atas buah jeruk Brastagi, dimana dapat dijangkau oleh daya beli konsumen pada umumnya.

Demikian juga permintaan pedagang pengecer terhadap buah salak ( pada saat penelitian buah ini didatangkan dari luar propinsi Bengkulu atau dari Padang Sidempuan sumatera Utara ) dan juga buah impor lainnya seperti apel merah, apel fuji, buah pear, dan buah anggur setiap bulan selalu diperjual belikan oleh pedagang pengecer. Hal ini mengindikasikan bahwa permintaan konsumen Kota Bengkulu terhadap buah import juga selalu ada sekalipun harga di tingkat konsumen relatif tinggi. Ini juga menggambarkan bahwa sudah mulai adanya kesadaran akan gizi pada masyarakat yang juga disebabkan kehidupan yang semakin baik.

\section{Faktor-Faktor yang mempengaruhi permintaan buah jeruk Brastagi}

Tabel 2. Hasil Analisis Regresi Beberapa Faktor yang Mempengaruhi Permintaan Buah Jeruk Brastagi pada Pedagang Pengecer di Kota Bengkulu

\begin{tabular}{|c|c|c|c|c|c|}
\hline \multicolumn{2}{|r|}{ Variabel } & \multirow{2}{*}{$\frac{\text { Mean }}{5575,1443}$} & \multirow{2}{*}{$\begin{array}{c}\text { Koefisien Regresi } \\
-0,2268\end{array}$} & \multirow{2}{*}{$\frac{\mathrm{Se}(\mathrm{bi})}{0,0088}$} & \multirow{2}{*}{$\frac{t_{\text {hitung }}}{-25,704}$} \\
\hline 1. & $X_{1}$ & & & & \\
\hline 2. & Yt-1 & 1129,8750 & 0,1030 & 0,2330 & 0,442 \\
\hline 3. & $x_{1} t-1$ & 6331,3320 & $-0,0103$ & 0,0060 & $-1,715$ \\
\hline 4. & $X_{2}$ & 2355,7703 & 0,0177 & 0,0091 & 1,931 \\
\hline 5. & $X_{3}$ & 7028609,55 & $1,76 \times 10^{-4}$ & $2,89 \times 10^{-6}$ & 60,891 \\
\hline 6. & $X_{4} t-1$ & 1099,60 & $-0,1154$ & 0,2418 & $-0,477$ \\
\hline 7. & $\mathrm{D}$ & 0,5000 & 5,8914 & 3,9548 & 1,490 \\
\hline \multicolumn{3}{|c|}{$\begin{array}{ll}\text { Konstanta } & =1316,8556 \\
\mathrm{R}^{2} & =0,9985 \\
\text { Se regresi } & =8,1771\end{array}$} & $\begin{array}{l}\mathrm{F}_{\text {hitung }} \\
\mathrm{t}_{\text {Tabel }}(0,05)(32) \\
\mathrm{F} \text { Tabel }(0,05)(\end{array}$ & $\begin{array}{l}=3000,249 \\
=2,031 \\
=2,29\end{array}$ & \\
\hline
\end{tabular}


Pada Tabel 2 diketahui bahwa nilai koefisien determinasi $\left(R^{2}=0,9985\right)$, hal ini memberikan indikasi bahwa nilai 0,9985 dan nilai $F$ hitung sangat signifikan yaitu sebesar 3000,249 dan setelah dilakukan uji t maka diperoleh variabel yang berpengaruh secara signifikan dalam model analisis regresi variabel harga beli jeruk Brastagi oleh pedagang pengecer $\left(X_{1}\right)$ dan modal usaha ( $\mathrm{X}_{3}$ ) sedangkan variabel lainnya tidak berpengaruh secara signifikan. Khusus harga beli buah jeruk Brastagi diperoleh dari hasil perkalian jumlah masing-masing jenis buah jeruk Brastagi ( Super, $A B, C$ ) setiap minggu dikali dengan harga masing-masing kelas jeruk Brastagi setiap minggu dalam satu bulan ( empat minggu ) dibagi dengan jumlah jeruk Brastagi yang dibeli secara keseluruhan.

J Supranto (1983) mengatakan bahwa mendeteksi Multikolinearity tidak mudah. Koefisien korelasi baik sederhana maupun parsial yang tinggi diantara variabel bebas kadang-kadang digunakan sebagai ukuran adanya Multikolinearity. Akan tetapi juga bahwa multikolinearity yang serius bisa terjadi walaupun koefisien korelasi sederhana atau parsial relatif nilainya rendah (misalnya kurang dari 0,5). Maka variabel yang dikeluarkan adalah variabel jumlah jeruk Brastagi yang dibeli oleh pedagang pengecer bulan lalu (Yt-1) dan harga beli jeruk Brastagi oleh pedagang pengecer bulan lalu $\left(X_{1} t-1\right)$ sedangkan modal usaha $\left(X_{3}\right)$ dan jumlah yang dibeli konsumen bulan lalu ( $\left.\mathrm{X}_{4} \mathrm{t}-1\right)$ tidak dikeluarkan dari model regresi karena dianggap relatif penting dalam mejelaskan pengaruhnya terhadap permintaan buah jeruk Brastagi pada pedagang pengecer, disamping meminimalkan lahirnya permasalahan baru yang akan timbul akibat dikeluarkannya beberapa variabel dari model.

Maka jumlah variabel bebasnya menjadi lima variabel yaitu variabel harga beli buah jeruk Brastagi oleh pedagang pengecer $\left(X_{1}\right)$, harga lokal jeruk Bengkulu $\left(X_{2}\right)$, modal usaha $\left(X_{3}\right)$, jumlah jerukBrastagi yang dibeli oleh konsumen bulan lalu ( $\left.\mathrm{X}_{4} \mathrm{t}-1\right)$ dan dummy (D) untuk jenis tempat usaha pedagang pengecer untuk hasil analisis regresi dengan mengeluarkan variabel (Yt-1) dan $\left(\mathrm{X}_{1} \mathrm{t}-1\right)$ diterangkan pada persamaan berikut menunjukkan bahwa dengan keluarnya variabel $\mathrm{Yt}-1$ dan $X_{1}$ t-1 dari model, maka $F$ hitung mengalami penurunan dari 3000,249 menjadi 44,783 sementara koefisien determinasinya ( $R^{2}$ ) juga mengalami penurunan yaitu dari 0,9985 menjadi $0,8682$ atau menurun sebesar 0,1303 ( $13,03 \%)$.

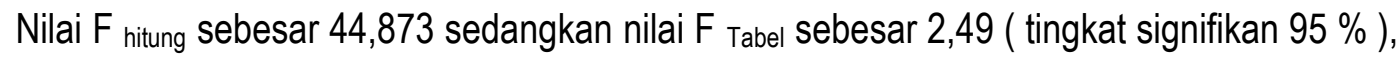
maka dapat dibandingkan bahwa nilai $F_{\text {hitung }}>F_{\text {Tabel }}$ atau hipotesis nol ( $\mathrm{Ho}$ ) ditolak pada taraf kepercayaan $95 \%$. Hal ini mengartikan bahwa secara bersama-sama variabel dependen yakni 
harga jeruk Brastagi yang dibeli oleh pedagang pengecer bulan ini $\left(X_{1}\right)$, harga jeruk lokal Bengkulu sebagai barang substitusi ( $\left.X_{2}\right)$, modal usaha ( $X_{3}$ ), jumlah jeruk Brastagi yang dibeli oleh konsumen bulan lalu ( $\mathrm{X}_{4} \mathrm{t}-1$ ) dan jenis tempat usaha berdagang oleh pedagang ( D ) berpengaruh secara signifikan terhadap variabel dependen yakni permintaan buah jeruk Brastagi pada pedagang pengecer di Kota Bengkulu.

Nilai koefisien determinasi ( $R^{2}$ ) sebesar 0,8682 menunjukkan bahwa besarnya persentase sumbangan yang diberikan oleh variabel bebas ( $\mathrm{X} i$ ) secara bersama-sama dalam model terhadap variabel tak bebas ( $Y$ ) adalah sebesar 86,82 \% sisanya 13,18\% diterangkan oleh variabel lain yang tak masuk dalam model, yang dalam hal ini diperkirakan seperti harga jeruk Brastagi di tingkat konsumen. Besarnya koefisien determinasi ini menunjukkan adanya kesesuaian dalam penggunaan variabel yang mempengaruhi permintaan pedagang pengecer terhadap buah jeruk Brastagi.

$$
\begin{array}{r}
Y=1414,5874-0,1494 X_{1}-0,0058 X_{2}+4,69 \times 10^{-5} X_{3}+0,2918 X_{4} t-1+94,3618 D \\
(0,0624) \quad(0,0722)\left(1,27 \times 10^{-5}\right) \quad(0,0602) \quad(31,5522)
\end{array}
$$

Keterangan ( ) = standar eror masing-masing variabel bebas

Selanjutnya secara parsial pengaruh dari variabel-variabel independen ( Xi ) terhadap permintaan ( $Y$ ) dapat diinterpretasikan sebagai berikut :

\section{Variabel harga beli jeruk Brastagi oleh pedagang pengecer $\left(X_{1}\right)$}

Hasil analisis regresi linier berganda pada Tabel 3 diperoleh nilai koefisien regresi untuk harga beli jeruk Brastagi oleh pedagang pengecer bulan ini $\left(X_{1}\right)$ adalah $\quad-0,1494$ dengan nilai thitung ( $-2,397)$. Nilai $t_{\text {hitung }}$ ini lebih besar dari nilai $t_{\text {Tabel }}$ yakni 2,031 Pada taraf kepercayaan 95 persen. Hal ini berarti secara parsial harga beli jeruk Brastagi oleh pedagang pengecer berpengaruh nyata terhadap permintaan buah jeruk Brastagi oleh pedagang pengecer ( $Y$ ). Nilai koefisien regresi $X_{1}$ bertanda negatif menunjukkan bahwa pengaruh atau hubungan yang terjadi adalah bersifat kebalikan, artinya bila harga beli jeruk Brastagi oleh pedagang pengecer meningkat Rp 1 maka permintaan pedagang pengecer terhadap jeruk Brastagi akan turun sebesar 0,1494 $\mathrm{kg}$ dengan asumsi variabel lain yang mempengaruhi permintaan pedagang pengecer konstan.

Hal ini cukup beralasan karena sesuai dengan teori ilmu ekonomi yang menyatakan bahwa apabila harga suatu barang naik, maka permintaan terhadap barang itu akan turun. Hasil penelitian Sitorus ( 2003 ) menyatakan apabila harga sayuran daun pada pedagang pengecer 
naik maka permintaan pedagang pengecer akan sayuran daun akan menurun, dan sebaliknya akan meningkat apabila harganya turun, artinya harga sayuran daun berpengaruh nyata pada taraf kepercayaan 95 persen terhadap permintaan sayuran daun oleh pedagang pengecer.

\section{Variabel harga beli jeruk lokal Bengkulu ( $\mathrm{X}_{2}$ )}

Harga beli barang substitusi ( jeruk lokal Bengkulu ) juga mempengaruhi permintaan pedagang pengecer terhadap jeruk Brastagi. Dari hasil analisis regresi pada Tabel 3 diperoleh nilai koefisien regresi untuk variabel harga jeruk lokal Bengkulu pada pedagang pengecer bulan ini $\left(X_{2}\right)$ adalah sebesar $-0,0058$ dengan nilai thitung yaitu $-0,080$ dan $t_{\text {Tabel }}$ sebesar 2,031 pada taraf kepercayaan 95 \% maka dapat dibandingkan bahwa thitung $<t_{\text {Tabel. }}$. Dengan demikian bahwa hipotesis nol ( $\mathrm{Ho}$ ) diterima pada taraf kepercayaan $95 \%$, artinya bahwa variabel harga beli jeruk lokal Bengkulu pada pedagang pengecer bulan ini $\left(X_{2}\right)$ berpengaruh tidak nyata terhadap permintaan buah jeruk Brastagi dan hubungannya bersifat negatif. Indikasi ini menggambarkan bahwa tingkat harga buah jeruk lokal lain tidak akan mempengaruhi jumlah permintaan pedagang pengecer terhadap jeruk Brastagi artinya pada saat harga buah jeruk lokal lain naik atau turun maka jumlah permintaan pedagang pengecer akan jeruk lokal relatif tetap. Hal ini juga dapat dilihat dari tingkat permintaan pedagang pengecer terhadap jeruk lokal Bengkulu setiap bulannya. Hal ini juga sesuai dengan penelitian Sitorus ( 2003 ) yang menyatakan bahwa harga sayuran lain berpengaruh tidak nyata terhadap permintaan sayuran daun pada pedagang pengecer sayuran daun pada taraf kepercayaan $95 \%$.

\section{Variabel modal usaha $\left(\mathrm{X}_{3}\right)$}

Modal usaha merupakan hal yang penting dalam setiap usaha yang dijalankan. Dalam penelitian ini modal yang dimaksud adalah modal yang dikeluarkan untuk membeli jeruk Brastagi. Dari hasil analisis regresi pada Tabel 3 diperoleh nilai koefisien regresi untuk variabel modal usaha ( $X_{3}$ ) adalah sebesar 4,69 × 10-5 dengan nilai $t_{\text {hitung }} 3,689$ dan $t_{\text {Tabel }}$ sebesar 2,031 pada taraf kepercayaan $95 \%$ maka dapat dibandingkan bahwa thitung $>t_{\text {Tabel. }}$. Hal ini mengindikasikan bahwa hipotesis nol ( Ho ) ditolak pada taraf kepercayaan 95 \%. Hal ini juga membuktikan bahwa variabel modal usaha $\left(\mathrm{X}_{3}\right)$ berpengaruh secara nyata terhadap permintaan buah jeruk Brastagi dan hubungannya bersifat positif. Artinya jika modal usaha $\quad\left(X_{3}\right)$ meningkat sebesar Rp 1 maka permintaan buah jeruk Brastagi akan meningkat sebesar 4,69 × 10-5 kg. Hal ini juga sejalan dengan teori ekonomi yang menyatakan bahwa modal berpengaruh terhadap suatu usaha yang sedang dijalankan. Artinya jika modal usaha yang dimiliki pedagang pengecer jeruk Brastagi 
rendah maka permintaan akan jeruk Brastagi juga akan rendah, demikian juga sebaliknya jika modal yang dimiliki tinggi maka permintaan akan jeruk Brastagi juga akan tinggi.

Hal ini juga sejalan dengan hasil penelitian Mulyani ( 2002 ) yang menyatakan bahwa modal kerja berpengaruh nyata terhadap permintaan pedagang pengecer telur puyuh pada taraf kepercayaan $99 \%$, karena besarnya modal kerja yang digunakan akan sangat berpengaruh pada banyaknya jumlah telur puyuh yang akan dibeli oleh pedagang pengecer, sebab semakin besar modal yang tersedia maka akan semakin besar pula jumlah telur puyuh yang dapat dibeli oleh pedagang pengecer.

Penelitian yang mempunyai kaitan yang sama telah diteliti oleh Sitorus ( 2003 ) yang menyatakan bahwa modal usaha berpengaruh nyata pada permintaan sayuran daun oleh pedagang pengecer pada taraf kepercayaan $95 \%$ yang mempunyai hubungan yang positif.

\section{Jumlah buah jeruk Brastagi yang dibeli oleh konsumen bulan lalu ( $\mathrm{X}_{4} \mathrm{t}-1$ )}

Permintaan pedagang pengecer akan buah jeruk Brastagi pada bulan ini juga dipengaruhi oleh jumlah jeruk terjual pada bulan lalu atau jumlah jeruk yang dibeli oleh konsumen bulan lalu. Dari hasil analisis regresi pada Tabel 3 diperoleh nilai koefisien regresi untuk variabel jumlah jeruk Brastagi yang dibeli oleh konsumen bulan lalu ( $\mathrm{X}_{4} \mathrm{t}-1$ ) adalah sebesar 0,2918 dengan nilai thitung 4,847 dan tTabel sebesar 2,031 pada taraf kepercayaan $95 \%$, maka dapat

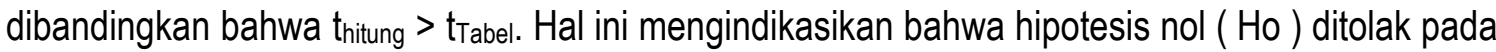
taraf kepercayaan $95 \%$, dengan kata lain bahwa variabel jumlah jeruk Brastagi yang dibeli oleh konsumen pada bulan lalu berpengaruh secara nyata terhadap permintaan buah jeruk Brastagi dan memiliki hubungan yang positif. Hal ini juga memberi arti apabila jumlah jeruk Brastagi yang dibeli oleh konsumen pada bulan lalu ( $\left.\mathrm{X}_{4} \mathrm{t}-1\right)$ meningkat sebesar $1 \mathrm{Kg}$ maka permintaan buah jeruk Brastagi pada pedagang pengecer bulan ini akan meningkat sebesar 0,2918 kg. Hal ini cukup beralasan karena jumlah yang terjual atau dibeli konsumen pada bulan lalu akan dijadikan sebagai perbandingan oleh pedagang pengecer untuk melakukan permintaan jeruk Brastagi pada bulan berikutnya, karena semakin banyak jumlah jeruk Brastagi yang dibeli atau yang terjual pada bulan yang lalu maka permintaan akan buah jeruk Brastagi pada pedagang pengecer pada bulan ini akan semakin banyak, sebaliknya apabila jumlah yang dibeli konsumen bulan lalu sedikit atau yang laku terjual sedikit maka pedagang pengecer akan mengurangi permintaannya akan jeruk Brastagi pada bulan berikutnya, dengan asumsi faktor lain yang mempengaruhi permintaan konstan. 
Hal ini sejalan dengan penelitian Muslimah ( 2001 ) yang menyatakan bahwa permintaan konsumen kemarin berpengaruh nyata terhadap permintaan sayuran kubis pada pedagang pengecer sayuran kubis pada taraf kepercayaan $99 \%$, karena jumlah permintaan konsumen kemarin dijadikan perbandingan oleh pedagang pengecer untuk melakukan permintaan sayuran kubis pada hari berikutnya.

\section{Variabel Dummy Jenis Tempat Usaha ( D )}

Dari analisis regresi pada Tabel 3 diperoleh nilai koefisien regresi untuk variabel jenis tempat usaha (D) adalah sebesar 94,3618 dengan nilai $t_{\text {hitung }}$ yaitu 2,991 $\geq$ t $_{\text {Tabel }}$ sebesar 2,031 pada taraf kepercayaan $95 \%$. Hal ini dapat diartikan bahwa hipotesis nol (Ho) ditolak pada taraf kepercayaan $95 \%$, dengan kata lain variabel dummy jenis tempat usaha (D) berpengaruh nyata terhadap permintaan jeruk Brastagi dan hubungannya bersifat positif. Artinya bahwa lokasi strategis tempat berjualan sangat menentukan terhadap tingkat penjualan barang dalam hal ini jeruk Brastagi. Keadaan ini dapat dilihat pada data yang ada bahwa rata-rata permintaan bulanan jeruk Brastagi antar pedagang pengecer yang tempatnya berupa Auning lebih besar daripada pedagang pengecer yang tempatnya berupa Emperan.

\section{Pendapatan Pedagang Pengecer Kota Bengkulu}

Di Pasar Minggu dan di Pasar Panorama ( baik yang auning dan emperan ) tidak ada satupun pedagang yang khusus menjual buah jeruk Brastagi saja, tetapi pada umumnya pedagang pengecer tersebut menjual berbagai macam buah-buahan oleh karena itu pedagang pengecer yang tidak menjual jeruk Brastagi saat ini sewaktu-waktu dapat menjual jeruk Brastagi di saat yang akan datang, ini tergantung pada keinginan dan kemampuan pedagang pengecer jeruk Brastagi dalam menjual buah jeruk Brastagi tersebut. Tetapi hasil penelitian membuktikan bahwa selama penelitian berlangsung tidak satupun pedagang pengecer yang tidak menjual jeruk Brastagi, hal ini mungkin disebabkan karena jeruk tersebut cukup laku di pasaran Bengkulu.

Tabel 3. Rata-rata Biaya tetap dalam pemasaran jeruk Brastagi pada pedagang pengecer Auning Kota Bengkulu perbulan.

\begin{tabular}{llllll}
\hline Jenis jeruk Brastagi & \multicolumn{3}{c}{ B. Penyusutan alat } & Retribusi & \multicolumn{2}{c}{ Sewa Tempat Total } & $\%$ \\
& $(\mathrm{Rp})$ & $(\mathrm{Rp})$ & $(\mathrm{Rp})$ & $(\mathrm{Rp})$ & \\
\hline 1. Jenis Super & 12715,88 & 2915,55 & 4337,90 & 19969,33 & 37,65 \\
2. Jenis AB & 11365,09 & 2190,68 & 3296,12 & 16851,89 & 31,77
\end{tabular}


3. Jenis C $\quad 8511,63 \quad 4504,66 \quad 3192,17 \quad 16208,45 \quad 30,57$

Sumber : Data primer diolah

Pada Tabel 3 dapat diketahui bahwa biaya tetap yang dikeluarkan oleh pedagang pengecer jeruk Brastagi yang Auning setiap bulannya adalah Rp 53.029,67. Dimana biaya tetap ini terdiri dari biaya penyusutan alat, biaya retribusi dan sewa tempat, yang berasal dari jeruk Brastagi jenis Super sebesar 37,65 \%, kemudian dari jeruk Brastagi jenis AB sebesar 31,77\%, serta dari jeruk Brastagi jenis $\mathrm{C}$ sebesar $30,57 \%$. Penyusutan alat ini terdiri dari penyusutan timbangan $10 \mathrm{Kg}$, Meja, Payung, Gerobak, Kursi dan kalkulator. Biaya tetap pada pedagang pengecer auning ini cukup tinggi karena pedagang pengecer harus mengeluarkan biaya sewa tempat setiap bulan.

Tabel 4. Rata-rata Biaya Tetap dalam Pemasaran Jeruk Brastagi pada Pedagang Pengecer Emperan Kota Bengkulu perbulan

\begin{tabular}{lccccc}
\hline Jenis jeruk Brastagi & $\begin{array}{c}\text { B. Penyusutan alat } \\
(\mathrm{Rp})\end{array}$ & $\begin{array}{r}\text { Retribusi } \\
(\mathrm{Rp})\end{array}$ & $\begin{array}{c}\text { Sewa Tempat } \\
(\mathrm{Rp})\end{array}$ & $\begin{array}{c}\text { Total } \\
(\mathrm{Rp})\end{array}$ & \multicolumn{2}{c}{$\%$} \\
\hline 1. Jenis Super & 18557,17 & 2719,09 & 0,00 & 21276,26 & 41,88 \\
2. Jenis AB & 14034,41 & 2127,61 & 0,00 & 16162,01 & 31,82 \\
3. Jenis C & 11223,70 & 2134,28 & 0,00 & 13357,98 & 26,30 \\
\hline
\end{tabular}

Sumber : Data primer diolah

Pada Tabel 4 diperoleh biaya tetap yang dikeluarkan oleh pedagang pengecer jeruk Brastagi yang emperan adalah sebesar Rp 50796,25 perbulan, berasal dari jeruk Brastagi jenis Super sebesar 41,88\%, kemudian dari jeruk Brastagi jenis AB sebesar 31,82\%, serta dari jeruk Brastagi jenis $\mathrm{C}$ sebesar $26,30 \%$. Namun angka ini relatif kecil dari biaya tetap yang dikeluar oleh pengecer Auning , karena pada pengecer emperan tidak mengeluarkan biaya untuk sewa tempat.

Penghitungan biaya penyusutan Alat dalam menjual jeruk Brastagi adalah harga awal dikurangi dengan harga akhirnya dibagi umur pemakaian alat tersebut, kemudian dibagi 12 untuk mendapatkan nilai penyusutan perbulan. Selanjutnya untuk menghitung penyusutan alat untuk jeruk Brastagi diperoleh dengan pendekatan hasil pembagian omset penjualan jeruk Brastagi dengan omset penjualan buah keseluruhan dikalikan besarnya biaya penyusutan. Kemudian untuk menghitung biaya penyusutan alat suatu jenis kelas jeruk Brastagi diperoleh dengan pendekatan hasil pembagian antara omset penjualan suatu jenis kelas jeruk Brastagi dengan omset penjualan keseluruhan jeruk Brastagi dikalikan besarnya biaya penyusutan jeruk Brastagi.

Setiap melaksanakan kegiatan berjualan barang di pasar, pedagang setiap harinya harus mengeluarkan biaya retribusi sebesar Rp 500 baik pada pedagang pengecer Auning maupun 
pengecer Emperan. Penghitungan biaya retribusi dalam menjual jeruk Brastagi adalah omset penjualan jeruk Brastagi dibagi dengan omset penjualan buah-buahan keseluruhan , kemudian dikali besarnya biaya retribusi untuk mendapatkan nilai retribusi perbulannya. Kemudian untuk menghitung biaya retribusi suatu jenis kelas jeruk Brastagi diperoleh dengan pendekatan hasil pembagian antara omset penjualan suatu jenis kelas jeruk Brastagi dengan omset penjualan keseluruhan jeruk Brastagi dikalikan besarnya biaya retribusi jeruk Brastagi.

Pedagang pengecer yang memiliki tempat khusus yang telah disediakan dipasar atau yang umum dikenal dengan tempat Auning wajib mengeluarkan sewa tempat setiap tahunnya, yang berkisar antara Rp 200.000 - Rp 400.000 pertahun. Sedangkan untuk pedagang pengecer Emperan, biaya sewa tempat tidak dikenai. Penghitungan biaya sewa tempat dalam menjual jeruk Brastagi adalah besarnya biaya sewa tempat dibagi 12 untuk mendapatkan nilai sewa tempat perbulannya. Selanjutnya Penghitungan biaya sewa tempat dalam menjual jeruk Brastagi adalah omset penjualan jeruk Brastagi dibagi dengan omset penjualan buah-buahan keseluruhan , kemudian dikali besarnya biaya sewa tempat untuk mendapatkan nilai sewa tempat perbulan. Kemudian untuk menghitung biaya sewa tempat suatu jenis kelas jeruk Brastagi diperoleh dengan pendekatan hasil pembagian antara omset penjualan suatu jenis kelas jeruk Brastagi dengan omset penjualan keseluruhan jeruk Brastagi dikalikan besarnya biaya sewa tempat jeruk Brastagi. Tabel 5. Rata-rata Biaya Variabel dalam Pemasaran Jeruk Brastagi pada Pedagang Pengecer Auning Kota Bengkulu perbulan

\begin{tabular}{lccccc}
\hline Jenis jeruk Brastagi & $\begin{array}{c}\text { B. Susut } \\
(\mathrm{Rp})\end{array}$ & $\begin{array}{c}\text { B. K. Plastik } \\
(\mathrm{Rp})\end{array}$ & $\begin{array}{c}\text { B. T. Kerja } \\
(\mathrm{Rp})\end{array}$ & $\begin{array}{c}\text { Total } \\
(\mathrm{Rp})\end{array}$ & $\%$ \\
\hline 1. Jenis Super & 105489,20 & 6333 & 56063,10 & 167885,30 & 39,08 \\
2. Jenis AB & 93466,95 & 7071,75 & 42197,33 & 142736,03 & 33,23 \\
3. Jenis C & 70495,20 & 6840,75 & 41543,62 & 118879,57 & 27,69 \\
\hline
\end{tabular}

Sumber : Data primer diolah

Pada Tabel 5 diperoleh bahwa untuk pedagang pengecer auning, besarnya biaya variabel yang dikeluarkan setiap bulan dalam pemasaran jeruk Brastagi adalah Rp 429.500,9 angka ini cukup tinggi karena memang harus diakui bahwa produk hasil pertanian seperti jeruk Brastagi ini memiliki sifat yang mudah rusak atau busuk sehingga buah jeruk Brastagi tiap bulannya mengalami kerusakan beberapa kilogram yang berakibat pada biaya susut yang semakin besar yang terbeban pada pedagang pengecer. Besarnya biaya variabel pada pedagang pengecer 
auning ini berasal dari besarnya biaya susut dari jeruk Brastagi jenis super yakni $\quad 39,08 \%$ kemudian diikuti biaya susut dari jeruk Brastagi jenis AB sebesar 33,23\% serta biaya susut dari jeruk Brastagi jenis C sebesar 27,69 \%. Naiknya biaya variabel ini merupakan konsekuensi dari banyaknya jeruk Brastagi yang rusak atau busuk sehingga tidak dapat diperjual belikan yang berakibat pada besarnya biaya pada penyusutannya. Sementara biaya kantong plastik dan biaya tenaga kerja pada masing-masing jenis jeruk tidak menunjukkan perbedaan yang cukup jauh.

Tabel 6. Rata-rata Biaya Variabel dalam Pemasaran Jeruk Brastagi pada Pedagang Pengecer Emperan Kota Bengkulu perbulan

\begin{tabular}{lcccll}
\hline Jenis jeruk Brastagi & $\begin{array}{c}\text { B. Susut } \\
(\mathrm{Rp})\end{array}$ & $\begin{array}{c}\text { B. K. Plastik } \\
(\mathrm{Rp})\end{array}$ & $\begin{array}{c}\text { B. T. Kerja } \\
(\mathrm{Rp})\end{array}$ & $\begin{array}{l}\text { Total } \\
(\mathrm{Rp})\end{array}$ & $\%$ \\
\hline 1. Jenis Super & 101000,30 & 5772 & 53889,96 & 160662,26 & 44,03 \\
2. Jenis AB & 65974,05 & 5351,25 & 42308,30 & 113633,60 & 31,14 \\
3. Jenis C & 44778,40 & 5155,50 & 40644,16 & 90578,06 & 24,83 \\
\hline
\end{tabular}

Sumber : Data primer diolah

Pada Tabel 6 diperoleh Pedagang pengecer emperan di Kota Bengkulu dalam menjalankan usaha berdagang setiap bulannya mengeluarkan biaya variabel sebesar Rp 364873,92. Besarnya biaya variabel pada pedagang pengecer auning ini berasal dari besarnya biaya susut dari jeruk Brastagi jenis super yakni 39,08 \% kemudian diikuti biaya susut dari jeruk Brastagi jenis AB sebesar 33,23 \% serta biaya susut dari jeruk Brastagi jenis $C$ sebesar 27,69 \%. Naiknya biaya variabel ini merupakan konsekuensi dari banyaknya jeruk Brastagi yang rusak atau busuk sehingga tidak dapat diperjual belikan yang berakibat pada besarnya biaya pada penyusutannya. Sementara biaya kantong plastik dan biaya tenaga kerja pada masing-masing jenis jeruk Brastagi tidak menunjukkan perbedaan yang cukup jauh. angka pengeluaran ini jauh di bawah rata-rata pengeluaran ( biaya variabel) oleh pedagang pengecer auning. Hal ini juga disebabkan karena rata-rata pedagang pengecer emperan tingkat permintaannya pada jeruk Brastagi lebih sedikit dari tingkat permintaan pedagang pengecer auning sehingga akan berakibat pada besarnya biaya variabel yang dikeluarkan oleh pedagang pengecer tersebut.

Biaya susut buah ini diperoleh dari jumlah buah jeruk Brastagi tiap jenis kelas yang susut atau rusak dikalikan dengan biaya susut dalam hal ini biaya pembelian rata-rata jenis kelas jeruk Brastagi tersebut. Penghitungan biaya kantong plastik sangat sulit ditentukan, khusus untuk buah jeruk Brastagi maka peneliti menggunakan pendekatan berdasarkan besarnya muatan jeruk 
Brastagi pada kantong plastik yang berukuran sedang yakni untuk satu kantong plastik mampu menampung $2 \mathrm{Kg}$ jeruk Brastagi dengan harga satu bungkus kantong plastik Rp 1500 yang isinya 50 lembar. Maka untuk menghitung nilai biaya kantong plastik dihitung dengan pendekatan jumlah jeruk Brastagi yang terjual untuk masing-masing kelas jeruk Brastagi dibagi dengan kapasitas muatan kantong plastik dikali dengan harga satu bungkus kantong sehingga besar biaya kantong plastik Rp 15 per kg jeruk Brastagi yang terjual (Muslimah, 2001 ).

Biaya tenaga kerja pada pedagang pengecer di Kota Bengkulu dikeluarkan untuk membiayai upah tenaga kerja dalam keluarga dimana upahnya diperhitungkan berkisar antara Rp 8500 - Rp 10.000 per harinya ( dalam satu bulan adalah 30 jumlah HOK/ hari orang kerja ). Penghitungan biaya tenaga kerja dalam menjual jeruk Brastagi adalah omset penjualan jeruk Brastagi dibagi dengan omset penjualan buah-buahan keseluruhan, kemudian dikali besarnya upah tenaga kerja untuk mendapatkan nilai tenaga kerja perbulannya. Kemudian untuk menghitung biaya tenaga kerja suatu jenis kelas jeruk Brastagi diperoleh dengan pendekatan hasil pembagian antara omset penjualan suatu jenis kelas jeruk Brastagi dengan omset penjualan keseluruhan jeruk Brastagi dikalikan besarnya biaya tenaga kerja jeruk Brastagi. Dari hasil uji statistik, maka didapat nilai $t$ hitung sebesar 0,315 < t tabel yaitu sebesar 2,445. hal ini menunjukkan bahwa secara statistik perbedaan pendapatan antara pedagang pengecer auning dan pedagang pengecer emperan adalah tidak nyata. Hal ini dikarenakan variasi pendapatan yang diperoleh antara pedagang auning dan emperan kecil, dengan perbedaan nominal sebesar Rp 149.842,45.

Hal ini juga dapat terlihat dari total penerimaan yang diperoleh pedagang pengecer auning sebesar Rp 2.037.962 yang tidak begitu jauh berbeda dari penerimaan yang diperoleh pedagang pengecer emperan yaitu Rp 1.821.223. kecilnya selisih penerimaan ini juga dapat ditunjukkan pada selisih total biaya yang kecil dimana total biaya pedagang pengecer auning yaitu Rp 482.530,57 sedangkan total biaya yang dikeluarkan pedagang pengecer emperan yaitu Rp 415.670,17. maka dengan demikian perbedaan pendapatan antara pedagang pengecer auning dan pedagang pengecer emperan secara nominal berbeda tetapi secara uji statistik tidak berbeda nyata.

\section{KESIMPULAN DAN SARAN}

\section{Kesimpulan}


1. Permintaan Jeruk Brastagi pada pedagang pengecer auning secara keseluruhan $1.398 \mathrm{Kg}$ perbulan lebih besar dari pada permintaan Jeruk Brastagi pada pedagang pengecer emperan yang hanya $1.122 \mathrm{Kg}$ perbulan.

2. Dari keseluruhan faktor yang mempengaruhi permintaan yang berpengaruh signifikan secara parsial terhadap permintaan Jeruk Brastagi adalah harga beli Jeruk Brastagi minggu ini (X1), modal usaha pedagang pengecer (X3), jumlah Jeruk Brastagi yang dibeli konsumen minggu sebelumnya $(X t-1)$ dan dummy tempat berdagang $(D)$, sedangkan yang tidak berpengaruh signifikan terhadap permintaan adalah harga beli Jeruk manis lokal $\left(\mathrm{X}_{2}\right)$.

3. Pendapatan pedagang pengecer Jeruk Brastagi auning (Rp 1.555.395 per bulan) lebih besar dari pada pendapatan pedagang pengecer jeruk Brastagi emperan (Rp 1.405.552. per bulan). Namun secara uji statistik perbedaan pendapatan antara pedagang pengecer auning dan emperan adalah tidak nyata, karena variasi pendapatan antara yang auning dan emperan cukup kecil yang disebabkan penerimaan dan total biaya antara pedagang pengecer auning dan pedagang pengecer emperan tidak jauh berbeda.

\section{Saran}

1. Untuk menambah modal usaha sebaiknya pedagang pengecer meminjam modal dari lembaga keuangan baik pemerintah atau swasta.

2. karena jenis tempat usaha berdagang mempengaruhi besar permintaan akan jeruk Brastagi maka pedagang pengecer dapat berjualan sebagai pengecer auning karena permintaan secara riil pendapatan pedagang pengecer auning lebih besar daripada pendapatan pedagang pengecer emperan.

3. Pemerintah daerah melalui Dinas Pasar Kota Bengkulu maupun pusat terminal Agribisnis Propinsi Bengkulu sebaiknya menyediakan informasi tentang harga komoditi jeruk Brastagi di Pasar sehingga dapat membantu pedagang pengecer maupun konsumen dalam melakukan kegiatan jual beli jeruk Brastagi sehari-hari.

4. Dari hasil penelitian yang diperoleh, untuk kedepan masih diharapkan adanya penelitian terhadap objek yang sama atau sejenis untuk lebih mengetahui tentang perlakuan permintaan dan pendapatan para pedagang pengecer jeruk Brastagi.

\section{DAFTAR PUSTAKA}

Abdurrachman. 1982. Ekonomi Keuangan Pedesaan. Pradya Paramita. Jakarta. 
Azzaino.1982. Pengantar Tataniaga Pertanian. Institut Pertanian Bogor. Bogor.

Ade Iwan, Trisnawati. 1992. Peluang Usaha dan Pembudidayaan Jeruk Siam. Penebar Swadaya. Jakarta

Arsyad, L. 1987. Iktisar Teori dan Soal Ekonomi Mikro. BPFE Yogjakarta.

Asri Marwan. 1986. Marketing. BPFE-Yogjakarta kerjasama dengan LMP2 AMP-YKPN. Yogjakarta

Badan Pusat Statistik. 2001. Laporan Tahunan Badan Pusat Statistik Propinsi Bengkulu, Bengkulu

Bilas , R. 1981. Microeconomic Theory.McGraw-Hill International Book Company.California

Breman. San.1995.Sistem Tenaga Kerja Dualistis Suatu Kritik Terhadap Sektor Informal, "Dalam Cris Maning (ed) Urbanisasi, Pengangguran, dan Sektor Informal di Kota Jakarta.Jakarta.

Diana. 1998. Sumbangan Industri Rumah Tangga Wanita Transmigrasi Terhadap Pendapatan Rumahtangga ( Kasus di Desa Sukajaya Lokasi Transmigran Sulau Kecamatan Manna Pembantu Keban Agung Kabupaten Bengkulu Selatan ). Skripsi. Fakultas Pertanian. UNIB. Bengkulu. Tidak Dipublikasikan.

Gumbira, Harizt Intan. 2001. Manajemen Agribisnis. Ghalia Indonesia.Jakarta

Hanafiah dan Saefudin. 1983. Tataniaga Hasil Perikanan. Rajawali Pers, Jakarta.

Irrantih, S. 1996. Kewirausahaan, Kaitannya dengan Pengembangan Usaha Kecil di Indonesia. Jurusan Sosial Ekonomi Pertanian. FP IPB.

Jurnal . 2003. Warta Penelitian dan Pengembangan Pertanian.

Jurnal. 2000. Warta Penelitian dan Pengembangan.

Jurnal Hortikultura. 1992. Pusat Penelitian dan Pengembangan Hortikultura. Jakarta

Jurnal Forum Penelitian Agro Ekonomi. 1997. Aspek Permintaan, Penawaran dan Tataniaga Hortikultura di Indonesia.

Kartasapoetra, G. 1992. Marketing Produk Pertanian dan Industri. Rineka Cipta. Jakarta

Komalig, A.1994. Perkembangan Struktur Kesempatan Kerja Di Pedesaan. Angkatan Kerja di Indonesia: Partisipasi, Kesempatan Kerja dan Pengangguran. CV. Rajawali. Jakarta.

Kotler.F. 2000. Manajemen Pemasaran. Penerbit Andi Yogjakarta. Yogjakarta.

Limbong, W. dan Panggabean Sitorus. 1987. Pengantar Tataniaga Pertanian. Jurusan IImu-IImu Sosial Ekonomi Pertanian Fakultas Pertanian. IPB, Bogor.

Muslimah . 2001. Analisis Permintaan dan Efisiensi Pemasaran Sayur Kubis di Tingkat Pedagang Pengecer Pasar Minggu Kota Bengkulu

Nazir, M. 1988. Metode Penelitian.Ghalia Indonesia. Jakarta.

Palungkun, R dan Budiarti. 2001. Sayuran Komersial. Swadaya, Jakarta.

Rahardi, Palungkun dan Budiarti. 2001. Agribisnis Tanaman Hortikultura. Penebar Swadaya, Jakarta. 
PERHEPI. 1998. Agro - Ekonomika. Jakarta

Saydam, G. 1996. Manajemen Sumber Daya Manusia. PT. Toko Gunung Agung, Jakarta.

Schumacher, E. 1994. IImu Ekonomi yang Mementingkan Rakyat Kecil. LP3ES. Jakarta.

Silalahi, B. N. 1994. Perencanaan dan Pembinaan Tenaga Kerja Perusahaan. PT Pustaka Binaan Pressindo. Jakarta.

Simanjuntak, Payaman.1985. Ekonomi Sumber Daya Manusia. LPFE UI.Jakarta.

Sinaga, R.S.1994. Beberapa Bukti Yang Menunjukkan Pergeseran Pola Kesempatan Kerja di Pedesaan Jawa, Sebab-Sebab Pergeseran dan Implikasinya. Institut Pertanian Bogor. Bogor.

Singarimbun, Masri dan Effendi.S. 1995. Metode Penelitian Survai. LP3ES. Jakarta.

Sudarsono. 1995. Pengantar Ekonomi Mikro, Modul UT. Karunika Jakarta UT, Jakarta.

Sudarso. 1991. Pengantar Ekonomi Mikro. Rineka Cipta. Jakarta

Sukartawi. 1993. Prinsip Dasar Manajemen Pemasaran Hasil-Hasil Pertanian. Raja Grafindo, Jakarta.

Sukirno,S.1985. Ekonomi Pembangunan. LPFEUI. Jakarta

Sumardi. 1982. Kemiskinan Dan Kebutuhan. Rajawali press. Jakarta.

Sumardi dan Mulyanto. 1985. Kemiskinan dan Kebutuhan Pokok. Rajawali Press. Jakarta.

Suparmoko. 1992. Ekonomika untuk Manajer. BPFE-Yogjakarta.

Supranto.J. 1982. Teknik Riset Pemasaran dan Ramalan Penjualan. Rineka Cipta. Jakarta.

Supranto. 1983. ekonometrika. Jilid II. UI Press, Jakarta.

Sutomo, S dan Sulistini. 1987. Distribusi Pendapatan dan Pola Pengeluaran Rumah Tangga, Pengamatan Berdasarkan SNSE 1975 dan 1980. Ekonomi Dan Keuangan Indonesia.PT. Raja Grafindo Persada. Jakarta.

Swastha Basu. 1984. Azas-Azas Marketing. BPFE-UGM. Yogjakarta.

Swasta Basu, Ibnu Sukotjo. 1988. Pengantar Ekonomi Perusahaan Modern. Penerbit Liberty. Yogjakarta.

Wilson Aubrey. 1982. Manajemen Pemasaran dan Jasa. PT. Pustaka Binaman Pressindo. Jakarta

Winardi.1985. Pengantar IImu Pemasaran ( Marketing ). Penerbit Tarsito. Bandung

Winardi. 1992. Aspek-Aspek Manajemen Pemasaran ( Pasar, Strategi Pemasaran, Segmentasi Pasar,. Diferensiasi Produk). Cv. Mandar Jaya. Bandung

Yitnosumato,S. 1994. Dasar-Dasar Statistika. Ed.I.Cet.2.PT. Raja Grafindo Persada. Jakarta. 